Meta

Journal des traducteurs

Translators' Journal

BrzozowsKi, Jerzy (2015): Autour de la traduction. Paris:

Orizons, 280 p.

\title{
Gleb Dmitrienko
}

Volume 62, numéro 2, août 2017

URI : https://id.erudit.org/iderudit/1041039ar

DOI : https://doi.org/10.7202/1041039ar

Aller au sommaire du numéro

Éditeur(s)

Les Presses de l’Université de Montréal

ISSN

0026-0452 (imprimé)

1492-1421 (numérique)

Découvrir la revue

Citer ce compte rendu

Dmitrienko, G. (2017). Compte rendu de [BRzozowski, Jerzy (2015): Autour de

la traduction. Paris: Orizons, 280 p.] Meta, 62(2), 475-478.

https://doi.org/10.7202/1041039ar

Ce document est protégé par la loi sur le droit d'auteur. L'utilisation des services d'Érudit (y compris la reproduction) est assujettie à sa politique d'utilisation que vous pouvez consulter en ligne.

https://apropos.erudit.org/fr/usagers/politique-dutilisation/
Cet article est diffusé et préservé par Érudit.

Érudit est un consortium interuniversitaire sans but lucratif composé de l'Université de Montréal, l'Université Laval et l'Université du Québec à Montréal. Il a pour mission la promotion et la valorisation de la recherche. https://www.erudit.org/fr/ 
Una de las claves de este trabajo tiene que ver con el concepto de "intimidad transcultural" ("transcultural intimacy”, empleado, según indica la propia Susam-Sareva, por Bigenho 2012, Herzfeld 1997, o Stokes 2010). Gracias a este, la autora será de capaz de trasmitir a un público académico internacional nociones intrínsecas a la cultura de masas propias de un país (o de dos, en este caso), solo comprendidas, en principio y de forma nostálgica y sentimental, por griegos y turcos.

La elección del estudio de caso está íntimamente ligada, tal y como se explica al lector al inicio de la obra, no solo a motivos de carácter biográfico, sino también a motivos sociológicos, ya que la música griega ha tenido gran importancia en la sociedad turca a finales del siglo XX y principios del XXI. Susam-Saraeva creció escuchando canciones griegas y turcas y posee un vasto conocimiento sobre la relación musical entre ambos países, el cual queda plasmado en las numerosas y continuas referencias discográficas y bibliográficas. Debido a esta amplia cultura, no solo traductológica, sino también musical y sociológica, el análisis realizado en el libro se va a extender y entrelazar con otras muchas disciplinas, como son el estudio de la música popular, la etnomusicología, los estudios griegos y turcos, la sociología de la música o el tan actual y novedoso fenómeno fan. Esta inter y multidisciplinariedad queda patente en la manera en que está estructurada la obra, donde además se mezclan el estudio de las diferentes etapas que afectan a la producción y consumo de música pop con las diferentes técnicas o estrategias de traducción que se pueden dar este género musical.

Uno de los capítulos más innovadores del libro es el que trata el fenómeno fan, aplicado en este caso a los foros de traducción de canciones pop en Internet. La autora examina y describe de forma esclarecedora muchos de los elementos que caracterizan esta práctica social y traductora, como, por ejemplo, el funcionamiento de los foros (uso de alias, imágenes o símbolos por parte de sus integrantes), el ambiente cordial y respetuoso que suele imperar en estos medios de comunicación o el uso del inglés como lingua franca o de enlace cuando surgen dudas de significado.

En sus conclusiones, Susam-Saraeva insiste en la importancia sociopolítica de la música pop y la traducción. Durante toda la investigación, la autora ha hecho especial hincapié en cómo la música y su traducción (ya sea lingüística o no) interfieren en el acercamiento de culturas y en la ruptura de barreras sociales o prejuicios. Esta obra es, sin lugar a dudas, una prueba de ello.

Rocío García JimÉnEZ Universidad de Málaga, Málaga, España

\section{REFERENCIAS}

Franzon, Johan (2001): The Pseudotranslation of Popular Songs, in Pirjo Kukkonen \& Ritva Hartama-Heinonen (eds.) (2001): Mission, Vision, Strategies and Values. A Celebration of Tranlator Training and Translation Studies in Kouvola. Helsinki: Helsinki University Press: 33-44.

Franzon, Johan (2008): Choices in Song Translation. Singability in Print, Subtitles and Song Performance. The Translator 14 (2): 373-99.

KaIndL, Klaus (2004): Die Welt ist schön, Mylord: Zum Genre- und Diskurstranfer in der Popularmusik, in Ina Müller (ed.) (2004): Und sie bewegt sich doch! Heidemarie Salevsky zum 60.Geburstag. Frankfurt am Main: Peter Lang: 177-96.

KaIndL, Klaus (2005): The Plurisemiotics of Pop Song Translation: Words, Music, Voice and Image, in Dinda L. Gorlée (ed.) (2005): Song and Significance, Virtues and Vices of Vocal Translation. Amsterdan / New York: Rodopi: 235-62.

Low, Peter (2003a): Singable Translation of Songs. Perspectives 11(2): 87-103.

Low, Peter (2003b): Translating Poetic Songs. An Attempt to Functional Account of Strategies. Target 15(1): 95-115.

Low, Peter (2005): The Pentathlon Approach to Translating Songs, in Dinda L. Gorlée (ed.) (2005): Song and Significance. Virtues and Vices of Vocal Translation. Amsterdam / New York: Rodopi: 185-212.

Low, Peter (2017): Translating Song. Lyrics and Text. New York: Routledge.

Brzozowski, Jerzy (2015): Autour de la traduction. Paris: Orizons, 280 p.

It's been argued recently by some translation scholars (Chesterman 2006, Simeoni 2007 among others) that the observable expansion of Translation and Interpretation Studies (TIS) over the past few decades was due to a series of paradigm shifts or "turns" which marked the transition of the Western TIS from the narrowly linguistic context towards much broader horizons of "poststructural" multidisciplinarity. However, the recent turns towards cultural, social or gender studies had some visible side effects on the contemporary human sciences. On the one hand, the abovementioned turns in human sciences have eroded the domain boundaries thus leading to the "end of theory" in its traditional understanding. On the other hand, the retreat from the "old school" formalist paradigm has led to significant depreciation of some formalist approaches developed within other scholarly practices and to their consequent elimination from the map of legitimate research 
within the Western scholarly tradition thus creating a theoretical gap between "the West and the rest" (Simeoni 2007: 17). At the same time, even within the Western tradition, translation scholars still lack a shared understanding of how to delineate the actual context of research (Chesterman 2006: 9) as they may be faced with two diverging strategies: while transatlantic scholars tend to align themselves with cultural or social moves which seem to deny any disciplinary boundaries, their colleagues in Europe, where structuralism was more firmly entrenched, are more inclined to work from within the more traditional fields of human sciences (Simeoni 2007). The necessity to take into account various diverging strategies becomes especially important if taking the challenge to discover the development of human sciences in "frontier countries" where the national scholarly tradition developed under the influence of two or more competing paradigms as happened, for example, with the Translation Studies in Poland.

Throughout all its history and especially in the last two centuries, Poland has been alternately influenced by two opposite cultural and political forces. Culturally, Polish scholars have always aligned themselves with the European tradition, while politically Poland was constantly affected by its closest neighbour - Russia. Of course, this controversial duality could not help shaping the Polish field of translation. This assumption may be easily supported by the recent monograph "Autour de la traduction" by Brzozowski, published in 2015 in Paris.

The book by this eminent Polish translation scholar and translator is a collection of fourteen articles which he wrote and published in the French language from 1997 to 2015 . The selected publications represent "successive steps of the research on the comparative literature" (p. 14). Seeking "to provide his reader with descriptive tools for translation analysis” (p. 16), Brzozowski gives his book a symbolic title - "Autour de la traduction" which is a perfect solution for a collection of papers which deal with a vast range of problems in the field of translation. Besides, the book's title echoes one of the preceding publications of Orizons edition - "Autour de la retraduction" (Monti and Schnyder 2012).

Brzozowski's monograph comprises three parts with each one of them addressing a particular set of translational problems. Thus, the division of the book allows some subject differentiation of the articles presented in each partition. However, one can't help noticing the fact that as a scholar specializing in comparative literature, Brzozowski has allocated two thirds of his book to particular questions of literary translation. A closer look at the second and third partition of the book allows to conclude that the difference between those two lies in the object of research rather than in its subject. Both partitions present several case studies in literary translation though unlike the variability of authors and genres of translation presented in the second part, his last "chapter" sets its focus on the translations of French romanticists: Baudelaire (who is of particular interest to the author), Verlaine and Hugo. Furthermore, the attention of the author and his reader is drawn to the poetic translations of the three iconic figures of French Romanticism.

It is worth underlining from the very beginning that the main theoretical framework for the analysis, which Brzozowski presents to readers, corresponds to comparative linguistics, to literal studies, and partially to contemporary translatology. This may partially explain the gravitation of the author towards the linguistic approach to translation as well as to the critics of Berman, to the poetics of Meschonnic and to the hermeneutics of Derrida. Thus, we may regard Brzozowski's monograph as a symbolic representation of the European, or rather Eastern European "frontier" translatology.

The first part of the book, which is entitled "La théorie de la traduction" presents the reader with four articles on the theoretical questions of modern translatology. Speaking about the partition title itself, one may notice that it is more common for the Eastern European scientific tradition. "La théorie" here doesn't mean any particular theory, but marks the differentiation between translation practice and theoretical problems of translatology, thus combining existing domain theories under one generic name [cf. Linguistic Theory of Translation in Russian TS (Fedorov 1953/2002; Shvejcer 1973; Retsker 1974; Komissarov 2002; for an overview of the historical development of the Linguistic theory of Translation in Russia, see Dmitrienko 2015)]. However, "La théorie" opens with a discussion on a question which has already become a cornerstone of Western TIS - the one about the place of translatology within the human sciences (pp. 19-38). Referring back to the article by Holmes and its critics presented by Toury and other scholars, Brzozowski proposes a reconceptualized Map of TIS which includes multidirectional and reciprocal relations between different domains within TIS and which shows the contributions of other disciplines to translatology. Besides, the author insists on paying more attention to descriptive poetics, which marks his adherence to literal studies (p. 28), and to translation critics which is an obvious reference to Berman (1995). It is remarkable that speaking about the theory of translation and descriptive poetics, Brzozowski implicitly describes the Polish translatological tradition. The author notes that the scholars who 
favour linguistic approaches, and in particular those who study "pragmatic texts," prefer the term "theory of translation" to the term "poetics" majorly employed by whose interest lies in literal translation (p. 27). According to Brzozowski, contemporary Theory of translation should take into account relevant linguistic theories as well as those of literary studies though they may be incompatible or even competing (p. 35). The last statement brings us to the second article which is more synthetic and which deals majorly with the relations between modern TIS and philosophy. Within this contribution, Brzozowski analyses recent epistemological turns and their impact on the Translation Studies. The third article, "Le problème des stratégies du traduire", is already known to the Western Translation community as it was published in Meta (Brzozowski 2008). Speaking about different translation strategies, Brzozowski specifies that the article addresses only product-centred ones thus excluding all the strategies of the text selection process. Having provided the reader with a detailed overview of different approaches to define "translation strategies" as figures (Mauranen and Kujamäki 2004), deforming tendencies (Berman 1995), techniques or shifts (Chesterman 2005), the author concludes that a strategy is a form of "conscious" and "global" intervention which comes as a sum of a translator's decisions on different factors which usually overlap in their interaction. Thus, a strategy is always unique and "a-systemic" (p. 58), though the lack of coherence in defining a strategy itself creates some "fuzziness" in outlining different categories of translation strategies. Nevertheless, the author manages to provide his own classification of translation strategies which reflects different approaches and principles of classification (pp. 61- 69). Lastly, the fourth article of the "theoretical" partition presents the reader with Brzozowski's view of translation figures or techniques which, unlike translation strategies, are more "immediate and local." Defining a figure as a "conscious modification of the original text on the operational level in order to achieve a particular communicative effect on the recipient at the moment of speech," Brzozowski points out that it is a recognizable linguistic form which is always an example of a translator's creativity (p. 77). Thus, in order to provide the reader with a solid classification of translation figures, the author suggests taking the original classification proposed by Vinay and Darbelnet and complement it with Jakobson's view of functions of language while bearing in mind the distinction between the source and target language techniques suggested by Chesterman. As a result, the reader is presented with a comprehensive classification which contains three major classes of translation figures: those operating in a source language, the ones operating in the target language and a distinct class of hybrids. Further on, the figures fall into six groups according to the "immediate impact" which they are to create and which corresponds to one of the functions of language introduced by Jakobson: referential, conative, phatic, emotive, poetic and metalinguistic function.

The second partition, "Les auteurs $d u X X^{e}$ siècle," comprises six articles each presenting a case study in descriptive poetics of literal translation. Each contribution deals with a specific problem of literal translation although the proximity of some objects of study makes it possible to unite some of the contributions into separate clusters. Thus, the first three articles (pp. 129-174), which talk about genre-specific translations (prose, poetry, songs), all share contrastive analysis methodology based on the "systemic" rationalization of Berman and "sonorous" translation of Meschonnic. The second cluster which unites the fourth and the fifth articles deals with interdisciplinarity in literal translation. The fourth article (pp. 175-184) shows the interrelations between translation and philosophy trying to answer the question about how to translate philosophical texts. The objective of the fifth article (pp. 185-196) is to depict how translation practices may be influenced by ideology and power shifts. Finally, the partition closes with an article on poetic translation as seen through the prism of linguistic analysis (pp. 197-210). Starting with a debatable assumption that only poets can successfully deal with untranslatability of poetic texts (p. 197), Brzozowski explores the views of three outstanding poets and translators: Miłosz, Wat and Meschonnic on the "spirit of language" (le génie de la langue) and on poetry as the representation of the former. After a meticulous analysis, Brzozowski concludes that for Miłosz, language spirit lies in the past experience of people and their relationships with nature (p. 199) while poetry is the link which ties language with reality. For Wat, the language reflects discursive habits of people and their shared knowledge of history and culture (p. 203). Poetry is regarded as the set of intuitive and comprehensible allusions and references governed by literary conventions. Meschonnic sees the spirit of the language in its users, while poetry is a reference between a life form (forme de vie) and its representation in a discourse (forme de langage) (p. 209).

The last partition of the book is exclusively dedicated to three eminent figures of French Romanticism: Baudelaire, Hugo and Verlaine. Of these three, Victor Hugo is mostly known for his novels while Baudelaire and Verlaine mainly for their poetry. However, as one reads further in the book, it becomes clear that the author's main 
interest, even when he speaks about Hugo, lies in the research of poetry. Taking a closer look, we may conclude that all four articles which constitute the third part of the book are at least two-dimensional. As a scholar whose passion lies in literal studies and precisely in the research of Baudelaire's poetry, Brzozowski cannot help admiring "le génie" of the French Romanticism. On the other hand, as the book is dedicated to translation, the author finds a perfect combination of two different approaches to translation: he pairs linguistic and poetic analysis of the material with the analysis of its translations and their respective place in target cultures and literal systems; in particular - in Polish literature. Thus, the first two articles, dedicated majorly to Baudelaire and to a lesser extent to Verlaine (pp. 213-124), show the author's concern about the poetic analysis of stylistic figures and tropes describing either the urban landscape or the semantic field of "incredible ascension." Conversely, the third article (pp. 235-248) focuses on the polysystemic analysis of the recognition of Hugo's works in Poland. It is astonishing that despite the fact that the novels of Hugo were highly praised by the Polish readership, his poetry was significantly discredited due to certain ideological factors resulting in the cultural alienation of French Romanticism. The last article of the "poetic" partition (pp. 249-262) represents a vivid example of historiographical translatology as it is dedicated to the history of translation and retranslation of Baudelaire's poetry in Poland since its first introduction into Polish literal system in 1876. As a case study, Brzozowski has chosen a sonnet, "À une passante," which had been translated into the Polish language nine times over the period of a century. As a result, a scrupulous poetic and rhythmic analysis of all the nine translations has allowed Brzozowski to draw an important conclusion about poetic translation in Poland: it has been a common rule for Polish translators to modernize the source text by translating the "ancient" poets in regular verses. Undoubtedly, this contributes to our better understanding of Polish tradition of translation.

In the conclusion, "Autour de la traduction" by Brzozowski would be a good choice for complementary reading for anyone interested in translation and particularly in literal translation and, as the author puts it, in its descriptive poetics. Moreover, the book sets up the pathways for research into the ways to combine the multidimensional Western (or rather Anglo-Saxon) Translation studies with Eastern European translatology which seems to maintain some relationships with linguistic structuralism.

Gleb Dmitrienko

Université de Montréal, Montréal, Canada

\section{REFERENCES}

Berman, Antoine. (1995). Pour une critique des traductions: John Donne. Paris: Gallimard.

Brzozowski, Jerzy. (2008). Le problème des stratégies du traduire. Meta: journal des traducteurs, 53(4):765-781.

Chesterman, Andrew. (2005). Problems with strategies. In: Krisztina KÁrolY and Ágota FóRIS, eds. New Trends in Translation Studies. Budapest: Akademiai Kiadó.

Chesterman, Andrew. (2006). Questions in the sociology of translation. In: João Ferreira Duarte, Alexandra Assis Rosa and Teresa SERUYA, eds. Translation Studies at the Interface of Disciplines. Amsterdam/Philadelphia: John Benjamins. 9-27.

Dmitrienko, Gleb. (2015). Vers une science de la traduction? Contextes idéologiques, politiques et institutionnels du développement de la Théorie Linguistique de la Traduction en Russie soviétique (1922-1991). Mémoire de maîtrise en traduction. Université de Montréal, Québec, Canada.

Fedorov, Andrei (1953/2002). Vvedenie v teoriyu perevoda [Introduction to the theory of translation]. Ed. 5. St.Petersbourg/Moscow: Philological department of SPbGU / Philologia Tri.

Komissarov, Vilen. (2002). Lingvisticheskoe perevodovedenie $v$ Rossii [Linguistic translation in Russia]. Moscow: ETS.

Mauranen, Anna and Kujamäki, Pekka, eds. (2004). Translation Universals. Do they exist? Amsterdam: John Benjamins.

Monti, Enrico and Schnyder, Peter, eds. (2012). La retraduction. Perspectives littéraires européennes. Avec un texte inédit de Jean-René Ladmiral. Paris: Orizons.

RetSKer, Yakov. (1974). Teoria perevoda i perevodcheskaja praktika [The theory and practice of translation]. Moscow: Mezhdunarodnye otnosheniya.

Shvejcer, Alexander. (1973). Perevod i lingvistika: Uchebnoe posobie dlya perevodchikov [Translation and Linguistics: Manual for translators]. Moscow: Voenizdat.

Simeoni, Daniel. (2007). Translation and society: The emergence of a conceptual relationship. In: Paul St-Pierre and Prafulla C. KAR, eds. Translation - Reflections, Refractions, Transformations. Amsterdam/Philadelphia: John Benjamins, 13-26

Navarro Domínguez, Fernando (ed.) (2015): Azorín y Miró en traducción. Alicante: Publicaciones de la Universidad de Alicante, 474 p.

Azorín y Miró en traducción es una obra colectiva, dirigida y coordinada por el profesor Fernando Navarro y editada por la Universidad de Alicante. Tal y como se indica en el mismo prólogo, recoge 